\title{
Federação, autoritarismo e democratização
}

\author{
BRASILIOSALLUM JR.
}

\begin{abstract}
RESUMO: O artigo analisa as relações federativas no Brasil durante o regime militar-autoritário, surgido depois do golpe militar de 1964. São estudadas as diferentes formas assumidas pelas relações federativas em diferentes períodos: na fase de máximo autoritarismo, que durou até 1973; nos anos de liberalização, de 1974 até 1982; e durante o ocaso do regime militar, de 1983 até início de 1985, período em que o Estado entrou em crise e os militares foram impedidos de continuar no poder por um processo de democratização política. São enfatizadas na análise as diferentes dimensões das relações intergovernamentais (econômicas, político-eleitorais e militares). Também se discute, à luz da experiência histórica em questão, a pertinência das interpretações correntes que identificam centralismo com autoritarismo e descentralização federativa com democracia.
\end{abstract}

\section{Introdução}

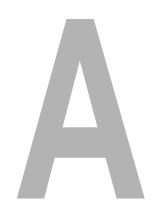

quase morte da autonomia dos estados da federação, no auge da ordem militar-autoritária de 1964, seu posterior despertar e subseqüente ressurgimento no ocaso do regime, parecem confirmar uma certa versão da história política brasileira. Aquela que a descreve como uma série sucessiva de sístoles e diástoles em que o poder ora se concentra autoritariamente na União, ora se dispersa democraticamente, ancorando-se nos estados.

Essa proposição, tornada famosa pelo general Golberi do Couto e Silva, conhecido estrategista do regime militar, está formalmente correta. No entanto, o conteúdo sociológico de cada movimento tem sido sempre diverso, o que pode tornar simplista a identificação imediata entre federação centrífuga e democracia, e entre federação centrípeta e autoritarismo.
UNITERIMOS:

Brasil, federação, militares, autoritarismo, democratização, estado, crise, transição política, desenvolvimento.

Este artigo é uma versão consideravelmente ampliada do texto elaborado para a pesquisa Balanço e Perspectivas do Federalismo no Brasil desenvolvida pelo Instituto de Economia do Setor Público da Fundap, órgão do governo do Estado de São Paulo.

Professor do Departamento de Sociologia da FFLCH-USP 
SALLUM JR., Brasilio. Federação, autoritarismo e democratização. Tempo Social; Rev. Sociol. USP, S. Paulo, 8(2): 27-52, outubro de 1996.

Quero, aqui, contribuir para superar esse simplismo, examinando as vicissitudes da federação no período da vigência e da superação do regime militar-autoritário à luz das transformações estruturais da sociedade brasileira.

Com esse propósito, estudarei a seguir o esmaecimento da federação ocorrido no período compreendido entre os anos de 1964 e 1973, a tentativa de reativá-la, no contexto do projeto Geisel de institucionalização (entre os anos 1974 e 1982), e o seu ressurgimento durante a crise política que levou ao fim do regime autoritário no começo de 1985.

\section{Golpe militar e regime populista}

O significado básico do movimento civil-militar de 1964, em relação às transformações socioeconômicas que marcaram o Brasil desde os anos 30 , tornou-se perceptível, tanto nas medidas repressivas tomadas pelo governo saído do golpe de $1^{\circ}$ de abril de 1964 como na política econômica que implantava, antes mesmo de constituir-se em regime político.

A quebra da ordem legal voltou-se contra a organização e a mobilização das classes subalternas, as políticas "artificiais" de distribuição da renda e da propriedade e as tentativas de conduzir o país na direção de um capitalismo mais autônomo e mais controlado pelo Estado. Tratava-se de evitar que as classes subalternas compartilhassem o poder de Estado, de impedir até que servissem de instrumento político utilizável nas disputas entre segmentos

Isso se deu, no plano econômico, através duma expansão extraordinária do capital financeiro. Ver a esse respeito José Carlos de Assis (1988, cap. I e II).

2 A mudança da forma da federação entre 1964 e 1973 não ocasionou mudança importante em termos de desenvolvimento regional. Como até 1973 a política econômica tratou basicamente de estimular as atividades econômicas já estabelecidas, o desenvolvimento industrial continuou concentrado em São Paulo (cerca de 50\% do produto industrial), tanto quanto o era no fim da década de 50 . Consultar sobre isso Wilson Cano (1979). da elite política pelo poder de Estado, de manter intocável a propriedade privada e de bloquear qualquer guinada do país na direção do mundo comunista.

Isso não é novidade. Há mais de vinte anos, Fernando Henrique Cardoso escrevia que "substancialmente esta intervenção [militar] se deu no momento em que eram postas em prática pelo governo medidas políticas de 'mobilização de massas', demagógicas ou não... em torno de alguns objetivos do regime nacional-populista: reforma agrária, ampliação da sindicalização, redistributivismo, regulamentação do capital estrangeiro, crescente estatização, etc." (Cardoso, 1973, p. 51).

Bloqueando tudo isso, o movimento civil-militar garantiu, no plano político, o curso do desenvolvimento socioeconômico anterior ${ }^{1}$, especialmente na forma que adquirira em meados da década de 50: industrialização intensiva, associada ao capital estrangeiro, tendente a concentrar-se regionalmente em São Paulo e a reforçar a regressividade na distribuição da renda ${ }^{2}$.

De início, logo depois do golpe, quando ainda não tinham consciência clara sobre a orientação que dariam ao país, os "revolucionários de 64" imaginaram cumprir seus objetivos apenas reforçando os poderes da Presidência da República, adotando uma política econômica austera e extirpando "cirurgicamente" do sistema político as lideranças vinculadas ao regime anterior. Lideranças que, por seu esquerdismo ou corrupção, haviam 
SALLUM JR., Brasilio. Federação, autoritarismo e democratização. Tempo Social; Rev. Sociol. USP, S. Paulo, 8(2): 27-52, outubro de 1996.

"desvirtuado" ou até "ameaçado" o caráter democrático do regime regulado pela Constituição de 1946. Reorganizadas as finanças públicas e "cortadas as cabeças" que punham em perigo a democracia, os militares devolveriam o poder aos civis. Federação, sistema partidário e eleitoral, garantias constitucionais - quase tudo, enfim, seria preservado.

No entanto, o exercício do governo foi mostrando aos poucos a incompatibilidade do antigo sistema político com a manutenção no poder da coalizão liberal-conservadora que ocupava o topo do Estado. Mais: os obstáculos criados ao exercício do poder "revolucionário" pela velha elite dirigente e a impopularidade ocasionada pela execução da política de estabilização de Roberto Campos e Gouveia de Bulhões (crédito restrito, "arrocho salarial" e eliminação das regras de estabilidade no emprego com a criação do Fundo de Garantia por Tempo de Serviço) tornaram previsível a derrota dos novos governantes em disputas eleitorais que se travassem nos velhos moldes. As eleições de outubro de 1965 - que colocavam em jogo o poder em 11 dos 22 estados da Federação - mostraram bem isso: apesar de todos os casuísmos dos quais se utilizou, o governo não conseguiu vencer a disputa.

Tornou-se claro então que, mantida a ordenação política anterior, a cirurgia política seria trabalho de Sísifo. De um lado, o governo militar ceifaria lideranças para conter o reformismo populista e, de outro, as regras eleitorais, os partidos e a ordem federativa, herdados do regime político anterior, continuariam a projetar para o alto do poder os remanescentes da velha elite dirigente e a dar-lhes espaço político para defender o status quo anterior. Manter-se-ía assim, aos olhos dos novos donos do poder, uma heterogeneidade perturbadora no comando do estado.

Mais ainda, os resultados das eleições de 3 de outubro de 1965 reiteraram uma das tendências mais marcantes do regime populista: a crescente autonomização do eleitorado urbano em relação ao controle de um sistema político alicerçado em elites políticas de base rural. Digo que reiteraram porque essa tendência manifestara-se antes de 1964, no crescimento paulatino do PTB em relação ao PSD e UDN e na emergência do fenômeno Jânio Quadros. Nas eleições de 1965, apesar das pressões contrárias, repetiu-se a antiga dinâmica, com o PSD aliando-se ao PTB nos estados mais urbanizados, como Minas e Rio de Janeiro, e derrotando os "revolucionários de 64", doutrinariamente vinculados à UDN.

Do ponto de vista "revolucionário", o elemento perturbador nas eleições não era apenas o crescimento da oposição política. O pior era que ela passasse a comandar parte do Executivo, isto é, governos estaduais que dispunham de certa autonomia política, lastreada em recursos financeiros e militares próprios. E, se a federação abria espaço para os adversários compartilharem o poder com os seus novos donos, o sistema partidário podia agravar a heterogeneidade da camada dirigente, na medida em que os partidos nacionais tinham uma organização fortemente regionalizada. 
Contudo, o que parecia mais grave aos novos donos do poder é que a quebra de unidade da elite dirigente e a competição por votos cada vez mais urbanizados podiam dar novo fôlego a movimentos de reforma social e política com participação popular, ou seja, poderiam recriar o ambiente político imediatamente anterior ao golpe de 64 .

Assim sendo, a política de "intervenção cirúrgica" - que desde o golpe já não contava com a simpatia dos setores "duros" das Forças Armadas - tornou-se um paliativo até aos olhos dos militares "moderados", vinculados ao presidente Castelo Branco, e à orientação da Escola Superior de Guerra. Havia que romper, portanto, as amarras que prendiam os novos governantes à constituição de 1946 e construir um novo regime político que impedisse que as massas populares se insinuassem pelas fraturas existentes entre as elites dirigentes.

\section{O formato institucional do regime autoritário}

O rompimento com o velho regime ocorre a partir de 27 de outubro de 1965, com a edição do Ato Institucional ${ }^{\circ} 2$. Ele é o ponto de partida de uma série de determinações que destroem boa parte das instituições políticas do pré-1964 e que passam a construir outras que terminam por converter o movimento civil-militar de $1964 \mathrm{em}$ um regime político singular que denominamos militar-autoritário.

Com a edição do AI-2, foi reiterada uma das características mais gerais do exercício do poder pelos "revolucionários de 64" em qualquer de suas fases: a duplicidade das práticas governamentais e do sistema de normas que as regulavam, no que diz respeito à fonte reivindicada de legitimidade (cf. Klein, 1978). Por isso, é unilateral a caracterização do regime como "ditadura" ou "república institucional", resultante de um poder "de fato", gerado pela "revolução de 64" e exercido de cima para baixo, arbitrariamente, por meio dos "atos institucionais". Não pode ser esquecido que os responsáveis pelo regime sempre reivindicaram também uma legitimidade dependente da formação de consensos entre os dominados. Por essa razão, foram preservados certos mecanismos característicos da democracia política, como um sistema partidário com um lugar limitado mas reconhecido para a oposição e consultas eleitorais restritas mas periódicas.

A duplicidade normativa, constitucional/institucional do regime militar-autoritário resultou das orientações político-ideológicas divergentes dos seus dirigentes. Esses segmentavam-se em facções heterogêneas agrupamentos militares, de composição variável no tempo, associados a equipes técnicas civis - que compartilhavam o poder, de forma tensa e até conflitiva, mas acomodando-se umas às outras, alternando-se na hierarquia de poder, mas evitando sempre romper a unidade "revolucionária".

Em termos sumários, o novo regime pode ser descrito por alguns traços básicos. O alicerce para sua construção foi, é claro, o controle militar 
SALLUM JR., Brasilio. Federação, autoritarismo e democratização. Tempo Social; Rev. Sociol. USP, S. Paulo, 8(2): 27-52, outubro de 1996.

da Presidência da República - o principal centro do poder político do sistema anterior a 1964 - e a imposição de limites à autonomia dos demais poderes da União: o Legislativo e Judiciário. Mas, como controlar a partir daí o sistema político? E como manter o poder sem quebrar a unidade entre as várias facções "revolucionárias", em meio a uma sociedade tão heterogênea e disponível aos apelos de participação? Como reproduzir como relação padronizada de domínio, o poder que se exercia de forma instável e por medidas ad hoc de repressão?

A resposta foi um conjunto de práticas e normas, por vezes arbitrárias mas com valor legal, com as seguintes características: a) desmobilizavam a sociedade, limitando a participação popular na política aos processos eleitorais; b) viesavam o sistema eleitoral, restringindo em extremo o peso do eleitorado das grandes cidades; c) tendiam a bloquear a expressão da heterogeneidade regional da sociedade através do esvaziamento da autonomia dos estados na Federação; d) reforçavam a homogenização dos quadros dirigentes pela imposição de um rígido sistema bipartidário; e) militarizavam o exercício do poder de Estado centralizado no governo federal.

Em suma, a resposta foi uma ordem política constituída, de um lado, por um sistema de filtros que bloqueavam, em progressão, a transposição de divergências existentes na sociedade para o plano político-institucional e, de outro, por mecanismos tendentes a unificar e centralizar a vontade política que conseguia representação no sistema.

Dentre os mecanismos que cumpriram o papel de homogeneizar a vontade política da camada dirigente, a nova forma da Federação, com estados e municípios menos autônomos em relação à União, desempenhou o papel mais relevante. Muito mais até que o novo sistema partidário, que tem recebido atenção muito maior da pesquisa acadêmica.

É que, contrariamente aos partidos - que na República de 1946 tinham participação reduzidíssima no exercício do governo - os estados cumpriram funções governativas importantes. Não só no plano regional, mas também, por vezes, no âmbito nacional, onde exerciam, principalmente, um poder de veto. Essas funções governativas tinham respaldo de forças militares estaduais (as Forças Públicas ou Brigadas Militares), o que não era nada desprezível, como se viu na resistência do governador do Rio Grande do Sul, Leonel Brizola, à tentativa de golpe militar contra o vice-presidente João Goulart, na sequiência da renúncia de Janio Quadros à Presidência da República. Além disso, o sistema eleitoral proporcional, segmentado por estados, transformava os governadores em chefes políticos, independentemente da ocupação formal de qualquer posição de direção nos partidos. Eram eles que controlavam grande parte dos recursos políticos passíveis de distribuição.

É por isso que a preservação da federação nos moldes anteriores ao golpe militar abriria a possibilidade não só de uma ampliação das divergências existentes na elite dirigente mas também de que tais divergências viessem a ser alicerçadas em recursos estatais de poder. Não foi por outra razão, como 
mostrei antes, que os resultados das eleições estaduais de 1965 desencadearam a reação que desembocou na construção do regime autoritário.

A nova federação, por um lado, reduziu drasticamente o poder dos estados federados e, portanto, dos grupos dirigentes regionais, e, por outro, fez dos governantes estaduais executores de políticas públicas definidas no âmbito nacional.

\section{A federação no interior do regime militar}

Um dos objetivos centrais do "federalismo de integração" implantado pelos "revolucionários de 1964" era esvaziar o poderio dos governadores de maneira que não pudessem colocar os recursos das administrações estaduais a serviço de movimentos ou organizações sociais que desafiassem as orientações do governo central ${ }^{3}$. No entanto, nesse aspecto, a nova Federação só atuava como instância de segundo grau.

Ela cumpria essa função lastreada por um sistema de filtros da vontade coletiva. A coluna central daquele sistema era constituída por práticas e normas tendentes a isolar institucionalmente o conjunto da sociedade da esfera política, de modo que os cidadãos que não fossem políticos profissionais só interviessem na vida pública no momento do voto. Esperava-se que, fora dos períodos eleitorais, cada membro da sociedade ou organização coletiva circunscrevesse suas atividades aos seus interesses particulares imediatos ou deles decorrentes - estudantes deviam estudar, operários trabalhar, padres rezar. A política deveria ser deixada aos políticos, ocupantes de funções públicas ou membros de partidos.

Os alvos básicos desta política desmobilizadora eram indivíduos, grupos e agências institucionais vinculados às políticas do governo derrubado, à aliança político-partidária que o sustentava, críticos em relação às políticas "revolucionárias" e, especialmente, os vinculados aos processos de ampliação da participação popular na política. Os instrumentos básicos para desenvolver esta estratégia desmobilizadora foram os atos institucionais e as comissões de inquérito, as intervenções e prisões decorrentes (Inquéritos Policiais Militares, Comissões Especiais de Investigação, intervenções, intimidações, cassações e prisões na esfera político-partidária, nas universidades, nas organizações estudantis e operárias), a Lei de Imprensa e a Lei de Segurança Nacional.

O sistema de representação política constituía outro dos filtros que bloqueavam a transposição para o Estado da heterogeneidade e do dissenso existentes na sociedade. As regras eleitorais características do regime tornaram extremamente viesada a representação: enquanto, por efeito do crescimento

A denominação "federalismo de integração" aparece por vezes em documentos oficiais do período analisado. capitalista, a sociedade se urbanizava concentrando-se cada vez mais em cidades médias e grandes, as regras privilegiavam o voto interiorano e rural mais sujeito ao controle clientelista do partido oficial, que fazia uso intenso das máquinas governamentais. Isso se deu, de um lado, pela preservação do voto de tipo proporcional para a escolha de candidatos às Câmaras Municipais, 
SALLUM JR., Brasilio. Federação, autoritarismo e democratização. Tempo Social; Rev. Sociol. USP, S. Paulo, 8(2): 27-52, outubro de 1996.

Assembléias Legislativas e Câmara dos Deputados e, por outro, por restrições à participação popular nas eleições. Primeiro, com a introdução de eleições indiretas - pelos parlamentos - para os candidatos a cargos no Executivo, presidente e governadores. Segundo, com a eliminação de eleições para prefeito das capitais e de municípios considerados "áreas de segurança nacional". Apenas os prefeitos das cidades do interior continuaram a ser eleitos diretamente.

O viés interiorano do voto de tipo proporcional não é, obviamente, inerente ao próprio mecanismo de escolha mas decorre de sua combinação com a estrutura demográfica e sóciopolítica do país. Com base nessa estrutura, o voto proporcional dá oportunidade para a formação de "currais eleitorais" no interior, compreendendo alguns municípios que garantem votação maciça a deputados "da região", que apenas usam o voto metropolitano, das grandes cidades e capitais, para "completar" o quociente mínimo exigido. Em contrapartida, era muito difícil um político eleger-se tendo como base principal o voto metropolitano, onde concentravam-se as massas populares e onde o seu controle político era mais difícil. Além disso, como nas capitais as estruturas políticas tinham como centro as prefeituras, elas mesmas dominadas pelos governos estadual e federal, o limitado controle que eventualmente existisse tendia a beneficiar os partidários do regime. Só na segunda fase do regime autoritário, de 1974 em diante, surgiram movimentos e organizações urbanas não controladas pelo poder central, dando mais chance a candidatos de oposição elegerem-se com base no voto das grandes cidades e áreas metropolitanas. Mesmo assim, até hoje, com plena liberdade de expressão e organização política, o voto proporcional ainda conserva um viés interiorano.

A discriminação política em relação às populações das regiões mais urbanizadas foi extraordinariamente reforçada pela introdução de eleições indiretas para o preenchimento dos cargos majoritários. Com isso, as grandes concentrações urbanas ficaram sem seu mecanismo mais favorável de expressão eleitoral, aquele que faz valer o seu caráter majoritário. Essa marginalização política ganhou sua expressão mais óbvia e extrema na eliminação das eleições para as prefeituras das capitais. De maior importância, porém, foi a redução do seu peso tanto na eleição presidencial como na de governadores.

Ademais, o sistema bipartidário instituído a partir do Ato Institucional $n^{\circ} 3$, de fevereiro de 1966, facilitava para o regime militar a seleção controlada de políticos profissionais, pois permitia distribuir recursos políticos seguindo a distinção simples amigo/inimigo. É claro que, na segunda fase do regime, quando alguns cargos majoritários passaram a ser escolhidos pelo voto direto, o sistema bipartidário passou a favorecer a oposição.

Por fim, pairava sobre esse conjunto de regras eleitorais - que por si mesmas distorciam a representação - a possibilidade, muitas vezes usada, de intervenção do poder "revolucionário", adiando eleições para época mais "conveniente", regulando a propaganda eleitoral para prejudicar a oposição, 
cassando mandatos e direitos políticos para evitar maiorias adversas nos parlamentos, etc.

Além de tornar muito difícil para os governadores colocarem recursos políticos estaduais a serviço de movimentos contestadores originados nas camadas populares ou nas elites regionais, o novo federalismo tinha outra função mais importante e construtiva. A função de homogeneizar, sob a égide do poder central, as elites que cumpriam tarefas de direção política, no seu modo de pensar e agir politicamente.

O sistema bipartidário reforçava essa função de dar homogeneidade às elites. Através das sublegendas abria-se um pouco o regime para a diversidade das correntes conservadoras existentes na sociedade, mas apenas para colocarem-nas em seguida sob a camisa de força da fidelidade partidária, que penalizava severamente o voto discordante. Discordante, é claro, em relação aos dirigentes do partido da "revolução", a ARENA, e, em última instância, do governo federal. Por outro lado, o bipartidarismo pasteurizava as diferenças existentes entre os que divergiam pacificamente do regime, obrigando-os praticamente a abrigarem-se sob um só partido de oposição "aceitável”, o $\mathrm{MDB}$, e a constituir uma elite dissidente em princípio controlável. Como, de fato, o foi na primeira fase do regime.

Por último - e não cabe aqui estender-me sobre isso - as Forças Armadas e a Comunidade de Informações, por meio de um complexo conjunto de órgãos subordinados ao Conselho de Segurança Nacional, disciplinavam exercício do poder, garantindo a unidade da classe dirigente em torno das diretrizes do governo federal.

\section{O esvaziamento das autonomias estaduais}

Foi o Ato Institucional n ${ }^{\circ} 3$, de 5 de fevereiro de 1966, que eliminou a participação popular direta da escolha dos governadores estaduais. As eleições passaram a ser feitas pelas assembléias legislativas dos estados. Com isso, tornou-se mais fácil controlar o processo através do uso de mecanismos fisiológicos de cooptação e da expectativa do eventual emprego da força dos atos institucionais.

De todo modo, as escolhas dos governadores resultavam de negociações mais ou menos duras entre diferentes facções das elites regionais, vinculadas em geral à "revolução" e ao seu partido, a ARENA, e o poder central, ele mesmo podendo apresentar divisões internas - a Presidência, os ministros militares, os comandantes militares regionais, os responsáveis pelos inquéritos policiais militares, etc. Em qualquer caso, o escolhido não assumia o poder considerando-se representante da vontade popular estadual, mas como "delegado da revolução" no seu estado. Nesse aspecto, vale enfatizar que nas eleições de 1966 e, principalmente, nas de 1970, as elites regionais tiveram um papel secundário. O presidente Médici, particularmente, procurava indicar nomes não comprometidos com os quadros políticos tradicionais nos estados, 
SALLUM JR., Brasilio. Federação, autoritarismo e democratização. Tempo Social; Rev. Sociol. USP, S. Paulo, 8(2): 27-52, outubro de 1996.

visando quebrar as estruturas oligárquicas preexistentes.

Nos casos em que o governo central não conseguisse impor, segundo as regras eleitorais vigentes, um candidato tolerável, fosse da ARENA - a grande maioria dos casos, fosse do MDB - caso do Rio de Janeiro, ele podia recorrer a expedientes autorizados por Atos Institucionais ou Complementares para conseguir seus objetivos. Podia decretar o recesso das Assembléias Legislativas recalcitrantes ( $\operatorname{art} .31$ do $\mathrm{AI} \mathrm{n}^{\circ} 2$ ), cassar mandatos e suspender direitos políticos por dez anos ( $\operatorname{art} .15$ do $\mathrm{AI} \mathrm{n}^{\circ} 2$ ), e conseguir, por meio de cassações, maioria nas assembléias, até porque os punidos não podiam ser substituídos e o quorum parlamentar se modificava ( $\$$ Único do Art. 15 do AI $\mathrm{n}^{\text {o }}$ 2). Com a Constituição de 1967, parte desse arbítrio desapareceu, mas depois do AI-5, de dezembro de 1968, ampliou-se em escala gigantesca ${ }^{4}$.

Casos exemplares disso, ainda em 1966, foram os do Rio Grande do Sul e São Paulo. No primeiro estado, foram cassados deputados da Assembléia Legislativa do Rio Grande do Sul porque parte da ARENA, com a participação do MDB, insistia em eleger um arenista considerado inconveniente pelo governo federal. No segundo, foi cassado o governador Ademar de Barros, participante do movimento de 64, mas que trabalhava para manter um esquema próprio de sustentação política com a participação de quadros estranhos à ARENA, o "partido da revolução".

Em toda a história das eleições indiretas para governador, em apenas um caso - o da escolha de Paulo Maluf para o governo do Estado de São Paulo em 1978 - o poder central foi diretamente contrariado. No entanto, já se vivia, então, a segunda fase do regime militar, quando os atos institucionais já estavam em vias de ser eliminados.

Mas, a tendência a restringir as autonomias estaduais em relação ao poder da União não se limitava ao processo de seleção de governadores "afinados" com o governo federal. Esse também conseguia moldar as políticas de governo dos escolhidos porque, a partir de 1965, as bases econômica e militar da autonomia dos estados foram drasticamente reduzidas.

$\mathrm{Na}$ área de segurança, os meios de sustentação militar da autonomia dos governadores foram "federalizados", isto é, passaram ao controle da União. Dois foram os mecanismos usados para isso.

Em primeiro lugar, determinou-se que os comandos das polícias militares devessem ser exercidos por oficiais do Exército. Além disso, as polícias militares passaram a subordinar-se a um órgão federal, a Inspetoria Geral das Polícias Militares, vinculada ao Estado Maior do Exército.

Em segundo lugar, tornou-se privativa de oficiais do Exército o exercício das secretarias estaduais de segurança, às quais se subordinaram tanto a polícia militar como a civil. Assim, todas as questões de segurança dos estados ficaram submetidos às Forças Armadas e à margem do controle dos governadores.

Essas restrições à autonomia dos governadores na área de segurança foram institucionalizadas entre fins de 1968 e meados de 1969, como um

${ }^{4}$ Consultar sobre o assunto Maria Helena Moreira Alves (1990, p. 90-95). 
SALLUM JR., Brasilio. Federação, autoritarismo e democratização. Tempo Social; Rev. Sociol. USP, S. Paulo, 8(2): 27-52, outubro de 1996.

${ }^{5}$ Consultar sobre a reforma tributária do início do regime autoritário Fabrício Augusto de Oliveira (1981). capítulo da luta entre os militares da "linha dura" que dominavam o governo federal e os remanescentes civis do "castelismo" que exerciam poder em alguns estados, como São Paulo, cujo governador era Roberto Abreu Sodré, e a Bahia, governada por Luiz Viana Filho. Isso vale especialmente para o primeiro, que exibia certa tolerância na repressão ao movimento estudantil contra o governo, muito forte naquele período (cf. Oliveira, 1976, p. 94).

Entretanto, muito antes disso, informalmente, a Presidência da República e o Exército já exerciam forte influência sobre as áreas de segurança dos estados. Não só pela atuação dos comandantes militares das várias unidades regionais das Forças Armadas mas também pela indicação oficiosa de nomes para ocupar os cargos-chave na área de segurança. O primeiro caso, ao que parece, ocorreu depois das eleições de outubro de 1965. O candidatos eleitos diretamente para governar Minas Gerais e Rio de Janeiro só puderam tomar posse sob a condição de nomearem indicados do governo federal para as respectivas secretarias de segurança. Mas talvez o exemplo mais claro, de que se implantava um padrão institucionalizado de interferência nos estados, tenha ocorrido quando da cassação do governador de São Paulo, Ademar de Barros, em 1966. Ao assumir o governo paulista, o vice-governador Laudo Natel - de absoluta confiança do "revolução" - "aceitou a indicação" do gal. Fragoso para a Secretaria de Segurança Pública e do coronel João Batista Figueiredo para comandante da Política Militar (cf. Viana Filho, 1976, p. 416). Essas indicações, depois do AI-3, passaram a ser consequiência "natural" das eleições indiretas em que o presidente da República tinha papel central, mas até 1968/69 não se tornaram regra.

Além destas restrições à sua autonomia militar, também foram afetadas as bases materiais do poder dos governos estaduais.

A reforma tributária, iniciada pela Emenda Constitucional $\mathrm{n}^{\circ} 18$, de outubro de 1965, desenvolvida no Código Tributário Nacional (CTN), de fevereiro de 1966, e consolidada na Constituição de 1967, restringiu os já escassos recursos alocados para os estados no período pré-64, colocando-os na dependência da União ${ }^{5}$.

De forma geral, a reforma orientou-se por uma concepção de sistema tributário nacionalmente integrado, em substituição à que admitia a coexistência de três sistemas autônomos — federal, estadual e municipal. Em conseqüência, aprofundou-se a dependência dos estados e municípios em relação à União. Essa passou a ter a competência de cobrar a maioria dos tributos, a absorver a maior parte da arrecadação e a centralizar as decisões sobre as aplicações dos recursos estaduais e municipais.

Assim é que, dos quatorze impostos do sistema tributário nacional, dez foram definidos como de competência da União: os impostos sobre importações, exportações, a propriedade territorial-rural (ITR), a renda (IR), produtos industrializados (IPI), operações financeiras (ISOF), transportes e comunicações, combustíveis e lubrificantes, energia elétrica e minerais. Desses impostos atribuídos à União, um havia sido dos estados (o de exportação) e 
SALLUM JR., Brasilio. Federação, autoritarismo e democratização. Tempo Social; Rev. Sociol. USP, S. Paulo, 8(2): 27-52, outubro de 1996.

um dos municípios (incidente sobre a propriedade rural).

Aos estados foram atribuídos dois impostos, sobre a transmissão de bens imóveis (ITBI) e sobre a circulação de mercadorias (ICM). O primeiro incorporou o antigo tributo sobre a transmissão de bens "causa mortis" e um imposto que era anteriormente dos municípios, o de transmissão de imóveis "inter-vivos".

Os municípios ficaram com competência de tributar a propriedade territorial urbana (IPTU) e os serviços de qualquer natureza (ISS).

Além dessa desproporção nas competências tributárias, o que por si só já dava mais flexibilidade decisória à União vis-a-vis estados e municípios, esses últimos foram proibidos de criar impostos, ao contrário da União que, desde a Constituição de 1967, recebe a chamada competência residual, isto é, lhe é atribuída a capacidade de criar novos impostos e sem a obrigatoriedade de partilhá-los com as entidades sub-nacionais.

Mais ainda: mesmo as alíquotas dos impostos estaduais, ICM e ITBI, não podiam ser fixados autonomamente pelos estados; o seu nível dependia de decisão do Senado e da sugestão da Presidência da República, o que no período autoritário era praticamente lei.

É claro que um sistema desbalanceado como este, com tamanha concentração de receitas nos cofres da União, inviabilizaria materialmente estados e municípios. Para compensar, pelo menos parcialmente, a desigualdade material - mas não o conseqüente desequilíbrio de poder entre as várias esferas da Federação - o sistema previa transferências de arrecadação tanto da União para os estados e municípios como dos estados para os municípios.

Com uma pequena parte do IPI e do IR recebidos pela União formou-se o Fundo de Participação dos Estados e Municípios, ficando os primeiros e o Distrito Federal com uma metade e os municípios com a outra, segundo critérios dependentes do volume da população e da renda per capita. Além do FPEM, parte dos impostos sobre lubrificantes, energia elétrica e minerais também era transferida da União para as unidades sub-nacionais.

As transferências para os estados podiam pesar muito do ponto de vista material. Um especialista, Aloisio Barbosa Araujo, calcula que elas tenham correspondido, em 1967, a 51,9\% das receitas dos estados da região Norte, 30,8\% das do Nordeste, 26,7\% das dos estados do Centro-oeste, 10,4\% das receitas do Sul e apenas 7,1\% daquelas do Sudeste. Em suma, quanto menos desenvolvidos os estados, mais dependiam de recursos da União, o que significava menor autonomia decisória.

Além disso, ao longo dos anos, as transferências para estados e municípios foram sendo reduzidas em favor da União, de modo que esta, ao invés das unidades subnacionais, pudesse absorver a maior parte dos benefícios da expansão econômica e do crescimento da arrecadação, ocorridos a partir de 1967. Assim, por exemplo, o Fundo de Participação dos Estados e Municípios (FPEM) que iniciara com $20 \%$ do conjunto do IPI e IR, segundo o Código Tributário Nacional, de 1966, passa a 14\% em 1967 e a 12\% pelo Ato 
Complementar nº 40, de 1968.

Do ponto de vista político, o essencial é que as transferências de recursos converteram-se em mecanismo de sujeição política dos governos estaduais ao poder central. Os recursos eram transferidos de forma condicionada. A União tutelava o modo como estados e municípios os dispendiam. O governo federal vinculava as transferências do FPEM a certos percentuais de gastos de capital (mais de 50\%) ou de gastos sociais com saúde, educação e saneamento. E as demais transferências, derivadas dos impostos sobre lubrificantes, energia elétrica e minerais, deveriam também ser gastas nos respectivos setores.

A diferença entre a forma de transferência de recursos da União para as unidades subnacionais, e dos estados para os municípios, confirma que a engenharia tributária do regime militar-autoritário decorria de sua engenharia política. Dentre todas as transferências de tributos para os municípios, somente as transferências de ICM dos estados - $20 \%$ do total arrecadado - podiam ser gastas livremente. O que significa que, ao transferir recursos para estados e municípios, a União ganhava o direito de fazer-lhes imposições, ao passo que com os estados não ocorria o mesmo. Em conseqüência, a relação de dependência dos municípios era apenas com a União, não com os estados e seus governadores. O que acentua o desenho politicamente centralizador do regime.

\section{Disciplina política e federação}

Esvaziando as condições (político-eleitorais, militares e tributárias) para o exercício relativamente autônomo dos poderes estaduais, o governo federal passou a orientar políticas regionais, quer por seus próprios organismos, quer pela moldagem das políticas dos governadores (Medeiros, 1986, p. 168-223).

Depois do golpe de 64, a presença direta do governo federal no âmbito regional aumentou por duas vias. Por um lado, pela expansão da própria máquina administrativa central: criou-se ou foram reforçados os escritórios regionais já existentes de ministérios como os da Fazenda, da Agricultura, da Educação, da Saúde e dos Transportes, etc. Por outro, o governo federal aumentou sua presença nos estados pela criação de extensões regionais das agências da administração descentralizada. Estas expandiram-se extraordinariamente desde a reforma administrativa de 1967 (Decreto-lei 200): em 1960, o governo central tinha apenas 49 agências descentralizadas (autarquias, fundações e empresas públicas); já em 1974, o número de agências chegava a 197.

Em outras palavras, cada ministério marcava presença direta nos estados tanto através dos seus escritórios regionais como através das extensões regionais de suas agências descentralizadas. Por exemplo, o Ministério da Fazenda tinha suas delegacias regionais e as extensões estaduais de suas agências descentralizadas, como o Banco do Brasil, a Caixa Econômica Federal, 
SALLUM JR., Brasilio. Federação, autoritarismo e democratização. Tempo Social; Rev. Sociol. USP, S. Paulo, 8(2): 27-52, outubro de 1996.

o Serpro, o Instituto de Resseguros do Brasil, etc.

As administrações estaduais tentaram reproduzir a estrutura da administração federal, criando secretarias correspondentes aos ministérios, estabelecendo sistemas de coordenação similares (cada estado tinha a sua secretaria do planejamento, como a vinculada à Presidência da República), e agências descentralizadas de função semelhante. Por exemplo: ao Departamento Nacional de Estradas de Rodagem (DNER) correspondiam, nas administrações estaduais, os Departamentos Estaduais de Estradas de Rodagem (DERs). Um especialista chama a atenção para o fato de que não se tratava apenas de repetir um esquema que era considerado tecnicamente superior mas de facilitar, pela similaridade dos órgãos estaduais e federais, a transferência de recursos da União para os estados.

O governo central moldava, assim, grande parte das atividades dos governos estaduais, com base na falta de autonomia político-partidária, militar e econômico-financeira dos governos estaduais e na relativa abundância de recursos, próprios ou de terceiros, controlados pela União, na possibilidade desta última condicionar a transferência destes recursos para estados e municípios.

Além das agências regionais dos órgãos federais atuarem com mais recursos em áreas que eram tradicionalmente de competência de estados e até de municípios, a União pautava a atuação dos governos estaduais através de convênios entre os distintos âmbitos da administração, transferindo-lhes verbas e fornecendo-lhes assistência técnica. Assim, programas estaduais de educação, por exemplo, desenvolviam-se sob orientação e sob controle federais, mediante convênio entre a secretaria do estado, o ministério da Educação, a secretaria estadual do Planejamento e a Secretaria para a Articulação com Estados e Municípios do Ministério do Planejamento. Isso valia, também, para as agências descentralizadas de cada estado, o que tendia a redirecionar seus vínculos de subordinação de fato para as agências federais correspondentes, enfraquecendo ainda mais os governos estaduais.

Em síntese, esvaziando a autonomia dos poderes estaduais e tendendo a fazer da federação um meio de execução descentralizada das políticas definidas pela União, os governos militares de 1964 até 1974 tentaram isolar a política da variabiabilidade da vida social e discipliná-la no molde definido pelo "núcleo revolucionário" que comandava o Estado. Construíram ao redor do poder central um conjunto de casamatas que filtravam as pressões da sociedade sobre o Estado - uma política de desmobilização social e de bloqueio da expressão política autônoma das concentrações urbanas. E, para reforçar a unidade política do Estado, enfraqueceram e uniformizaram de acordo com as determinações do governo federal, entre outras coisas, os centros de poder regional que pudessem desafiar o governo central.

Isso não significa, nem de longe, que tenha havido regularidade e constância nas políticas dos governos militares entre 1964 e 1974 . Pelo contrário, durante este período, a orientação econômica e política do governo 
central oscilou bastante-entre "duros" e "moderados", "estatistas"e "liberais", etc. O que importa, no entanto, é que tais mudanças de orientação ocorreram sempre em função dos resultados da luta entre facções político-militares (e os quadros técnicos associados a elas) que compartilhavam o poder central, sem que as elites políticas regionais tivessem nisso qualquer participação relevante.

Desta maneira, o regime autoritário e seu "federalismo de integração" permitiram a manutenção de alguns procedimentos democráticos para selecionar periodicamente quadros políticos, mas viesaram de tal modo a forma de escolha e esvaziaram tanto o poder dos escolhidos que apenas na cúpula do Estado havia espaço para a luta política.

\section{A liberalização e o despertar da federação}

A partir da escolha do general Ernesto Geisel para ocupar a Presidência da República, as relações federativas ganham nova dimensão no interior do regime militar-autoritário. Os centros de poder estaduais, até então excluídos da arena política principal, passam a ocupar posição importante no processo de institucionalização - por fim, fracassada - do regime autoritário e na tentativa de renovação do padrão anterior de desenvolvimento econômico.

Essa revalorização das relações federativas no quadro do regime autoritário estende-se de 1974, início do governo Geisel, até 1982, quando se realizaram eleições diretas dos governadores de estado e o governo brasileiro solicita moratória aos credores para sua dívida externa.

A revalorização da federação tornou-se fundamental para a realização do projeto Geisel/Golberi de institucionalização do regime não porque fosse o único ou o melhor caminho para liberalizá-lo. Tornou-se fundamental porque parecia a forma mais adequada do governo controlar o processo de institucionalização, especialmente depois da derrota sofrida nas eleições de 1974, quando os impulsos democratizantes originados nas concentrações urbanas começaram a mostrar sua força. Ela destinava-se a servir à liberalização controlada, nunca - é o que se verá - à democratização. Só depois, a partir de 1983, os governos estaduais e as elites regionais assumem um papel importante na superação do regime militar-autoritário e, portanto, no processo de democratização.

Com efeito, desde o seu início, os estrategistas da liberalização identificaram nos governadores de Estado as peças-chave que os ajudariam a isolar politicamente os setores "duros" das Forças Armadas e, ao mesmo tempo, formar uma elite política civil orientada pelos "ideais da revolução de 64" que pudesse manter-se no controle do novo regime, de tipo autoritário mas institucionalizado. Mais ainda: tentaram soldar esta "nova elite política" aos interesses dos grupos econômicos regionais, mediante uma política de desconcentração espacial de investimentos.

A estratégia de Geisel/Golberi em relação à federação aparece de forma incipiente na escolha mesma dos governadores de estado no ano 
SALLUM JR., Brasilio. Federação, autoritarismo e democratização. Tempo Social; Rev. Sociol. USP, S. Paulo, 8(2): 27-52, outubro de 1996.

de 1974.

Em primeiro lugar, houve uma tentativa séria de ampliar o papel das elites regionais na escolha dos chefes dos executivos estaduais. O governo imaginava que as envolvendo no processo obteria sua participação maciça na campanha eleitoral e, com isso, uma vitória consagradora nas eleições de 15 de novembro. É claro que frente a divergências insuperáveis, ou a um resultado “inconveniente", o presidente Geisel decidia. Mas era um tipo de intervenção bem distinta da eleição de 1970, no governo Médici, quando procurava-se em geral nomear quem não fosse associado a grupos políticos regionais.

Em segundo lugar, além da escolha orientar-se em função de candidaturas que pudessem ter um bom desempenho eleitoral, o presidente da República procurou selecionar governadores com capacidade de auxiliá-lo diretamente na execução da política de institucionalização do regime. Foi o caso das escolhas de Paulo Egídio Martins, em São Paulo, de Aureliano Chaves, em Minas Gerais, e de Sinval Guazelli, no Rio Grande do Sul, todos de orientação liberalizante e vinculados no passado à UDN, partido que dera respaldo à "revolução" nos momentos iniciais. O veto do presidente Geisel, na sucessão paulista, ao ex-ministro da Fazenda do governo Costa e Silva, da Junta Militar e do governo Médici, Antônio Delfim Neto, tem sentido análogo àquelas escolhas. Indica, a um só tempo, a intenção de não dar espaço para a "linha dura" militar e nem dar expressão ao empresariado paulista conservador que o considerava seu representante. $\mathrm{O}$ governo calculou que teria em Delfim um adversário da política de liberalização, de aprofundamento industrial e de desconcentração regional que pretendia desenvolver. Os governadores escolhidos cumpriram, de fato, o papel desejado pelo presidente, apoiando-o no combate à linha dura militar e auxiliando o Palácio do Planalto na execução da estratégia liberalizante.

A derrota do governo, nas eleições de novembro de 1974, acabou por exacerbar a estratégia governamental. A valorização política e econômica dos estados - a maioria pouco desenvolvida do ponto de vista econômico e passível de ser dominada, no plano político, por elites conservadoras - tornouse o meio privilegiado de controle da liberalização e, portanto, de bloqueio à democratização.

No plano político, a estratégia ganhou fôlego com uma sequiência de alterações nas regras eleitorais cuja constante foi aumentar o peso da representação política das regiões menos desenvolvidas e urbanizadas (mais controláveis pelos partidários do regime) e valorizar politicamente as elites regionais aliadas. Assim, fizeram-se restrições drásticas à propaganda política no rádio e na televisão nas campanhas municipais de $1976^{6}$, preservaramse as eleições indiretas para governador, adotou-se a eleição indireta de parte dos senadores (biônicos), incluiu-se a participação de representantes dos municípios nos colégios eleitorais que os elegiam, subdividiu-se estados pouco urbanizados e politicamente aliados, como Mato Grosso, em 1977, e, por fim, alterou-se em 1982 a composição do Colégio Eleitoral destinado a escolher o

${ }^{6}$ Mesmo quando "apenas" se restringe a propaganda gratuita no rádio e na TV, nas eleições municipais de 1976, o objetivo é o de favorecer as máquinas partidárias estaduais governistas. Bloqueava-se a difusão das críticas da oposição nas grandes cidades, onde ela era forte, mas dava-se livre curso à máquina partidária e governamental da ARENA, dominante nas pequenas e médias cidades do interior. 
SALLUM JR., Brasilio. Federação, autoritarismo e democratização. Tempo Social; Rev. Sociol. USP, S. Paulo, 8(2): 27-52, outubro de 1996.

Consultar sobre a desconcentração tributária desse período Rui Affonso (1988).

${ }^{8}$ Consultar a respeito Guilherme da Silva Dias e Basilia Aguirre (1993). presidente da República em 1985, dando mais peso às maiorias políticas existentes nas assembléias estaduais, que se esperava continuassem vinculadas ao regime. É claro que todas essas alterações, cujo horizonte era a formação de uma nova elite política civil que pudesse conduzir o regime, implicavam na valorização dos governadores, pilares estaduais da ARENA.

No plano tributário, a revalorização das elites regionais pelo projeto Geisel-Golberi de institucionalização resultou na inversão da tendência que concentrava recursos e decisões nas mãos do governo federal.

Foram três as modificações básicas ocorridas. Primeiro, os Fundos de Participação de Estados e Municípios tiveram suas alíquotas recompostas em $1 \%$ ao ano, de 14\% em 1975 para 20\% em 1979, quando chegaram ao nível original da reforma de 1966. Segundo, entre 1979 e 1980 foram eliminadas quase todas as condicionalidades impostas pela União para liberar transferências para estados e municípios. Terceiro, aumentam as alíquotas internas do ICM, principal tributo estadual, até atingir 17\% em todas as regiões do país.

Essas mudanças resultaram em maior disponibilidade de recursos tributários para os estados, especialmente para aqueles aos quais as verbas do Fundo de Participação dos Estados tinham mais importância. Mas, o principal é que reduziu-se a dependência política dos governadores em relação à União, em função da eliminação das condicionalidades para a liberação de transferências.

É verdade que a dependência se refez pela via financeira, na medida em que empréstimos controlados pela União - para saneamento, habitação, etc. - reintroduziram os controles sobre os governos estaduais. A diferença é que, nesse caso, a dependência resultava de uma opção política voluntária ${ }^{7}$.

Por último, a estratégia de institucionalização do regime tentou envolver na sua órbita não só as elites políticas regionais aliadas mas também grupos econômicos de importância local que lhes pudessem dar sustentação. Assim, o II PND tentou expandir em termos regionais o núcleo economicamente privilegiado da aliança desenvolvimentista, até então muito concentrado em São Paulo ${ }^{8}$.

Essa política começa antes mesmo da posse dos governadores escolhidos em 1974. Em agosto desse ano, Geisel lança o Programa de Pólos Agropecuários e Agrominerais da Amazônia. Em fevereiro de 1975, assina o Programa de Desenvolvimento do Cerrado (Polocentro). Nesse mesmo ano, em setembro, decide pela construção de um terceiro pólo petroquímico no Rio Grande do Sul, mesmo contra as pressões dos governadores de São Paulo e Bahia, que desejavam apenas a expansão dos pólos já existentes nos seus estados. E, na mesma época, resolve criar um complexo químico em Alagoas para exploração do sal-gema. Esses e muitos outros projetos desconcentradores foram lançados durante o governo Geisel.

Do ponto de vista político, a expectativa é que todas essas iniciativas soldassem grupos econômicos regionais, elites políticas estaduais e o projeto 
SALLUM JR., Brasilio. Federação, autoritarismo e democratização. Tempo Social; Rev. Sociol. USP, S. Paulo, 8(2): 27-52, outubro de 1996.

de institucionalização. Contudo, os resultados mostraram-se muito aquém do esperado.

A ligação entre grupos regionais e a institucionalização tendia a ser débil, em primeiro lugar, por razões estruturais: a ampliação das atividades capitalistas avançadas, acentuando a integração de cada região ao espaço do capitalismo moderno, reforçava algumas facções das elites regionais mas também aumentava a possibilidade de organização e mobilização da classe média moderna e dos assalariados produzidos no processo. Portanto, o que se destinava a consolidar a liberalização controlada alimentava também o processo de democratização que ameaçava ultrapassá-la. Isso não quer dizer que tendências político-partidárias reformistas, ancoradas nos segmentos médios e nos assalariados, fossem substituir necessariamente os velhos grupos políticos regionais. Como os acontecimentos políticos acabaram por mostrar, alguns desses velhos grupos puderam também "reciclar-se" politicamente, ganhar um feitio mais moderno, da sociedade de massas. Ou, em outros casos, minguaram, mas deram lugar a novas facções "conservadoras" de base urbana?.

Um segundo ponto negativo é que as tensões e conflitos emergentes nos vários níveis da própria organização política tornaram muito difícil o controle da mudança. $\mathrm{O}$ exemplo mais notório disso, mas não o mais importante, foi o da vitória da candidatura Paulo Maluf para o governo de São Paulo em 1978, a despeito da vontade do governo central. Isso foi possível porque o candidato Maluf aproveitou com habilidade a brecha aberta pelas disputas intestinas à ARENA de São Paulo e a desarticulação política ocorrida no poder central, durante a passagem de comando do presidente Geisel para seu sucessor, Figueiredo.

Foi, no entanto, durante o processo eleitoral de 1982 que as tensões nas relações federativas atingiram seriamente o projeto de institucionalização do regime autoritário. É claro que só o atingiram de forma secundária, pois ao tempo da campanha eleitoral de 1982 o projeto Geisel/Golberi já tinha sido inviabilizado pela mudança na correlação de forças entre os militares que sustentavam o regime e pela "nova" feição que aquela mudança provocara na vida político-partidária. Como se recorda, o episódio do Rio Centro dera ocasião a uma inflexão entre as diversas correntes político-militares que abalou a execução do projeto de institucionalização do regime e inviabilizou, com a reforma eleitoral de novembro de 1981, a flexibilização do sistema partidário, sublinhando sua polarização regime/anti-regime ${ }^{10}$.

Foi nesse contexto de perda de direção do processo de liberalização que a concessão de autonomia aos governadores acabou por acentuar os limites da institucionalização do regime autoritário. De fato, o que ocorreu é que os governadores acabaram conseguindo tanta autonomia que o efeito político disso foi semelhante ao ocasionado pelo enrijecimento partidário: um e outro processo acabaram por reduzir o peso eleitoral das hostes governistas. Explico melhor: com algumas medidas destinadas a regular as eleições de 82, o governo federal aumentou tanto a influência dos governadores na escolha dos
9 Num dos extremos parece estar, por exemplo, o grupo liderado por Antônio Carlos Magalhões na Bahia. No outro, estaria o caso de São Paulo, onde a polarização Janio Quadros/Ademar de Barros cedeu espaço para a "direita moderna" de Paulo Maluf.

${ }^{10}$ A decisão da cúpula militar de abafar o episódio do Rio Centro, quando dois militares feriram-se ao prepararem bombas que explodiriam no show de música popular comemorativo do $1^{\circ}$ de maio de 1981, sinalizou a derrota da facção militar vinculada ao ex-presidente Geisel que sustentava o projeto de liberalização. Foi vencida pela facção militar mais conservadora e profissional que decidiu impedir o julgamento de companheiros de farda vinculados à área de segurança de informação que combatiam a política "de abertura". Como resultado, o general Golberi demitiu-se do ministério Figueiredo. Esta reafirmação "revolucionária" da intocabilidade dos militares, projetou-se no plano partidário, eliminando a flexibilidade política introduzida pela multiplicação dos partidos e impedindo a absorção dos moderados da oposição (o Partido Popular) no bloco de sustentação da "abertura política" conduzida pelo governo. 
SALLUM JR., Brasilio. Federação, autoritarismo e democratização. Tempo Social; Rev. Sociol. USP, S. Paulo, 8(2): 27-52, outubro de 1996.

11 Segundo reportagem da Revista Isto é: "Esse complicado quadro de candidatos do PDS não surgiu gratuitamente. Sua construção pode ser atribuída ao poder de que os governadores gozam dentro da máquina partidária - conquistado graças aos casuísmos com que foi definida a legislação eleitoral. O primeiro passo para o domínio dos governadores foi dado ainda na fase de organização inicial dos partidos... (quando)...todo o trabalho (foi)... apoiado na ação dos governadores. Expirado o prazo, Brasilia prorrogou por mais dois anos o mandato dos diretórios, possibilitando que os governadores continuassem a controlálos. [...] A concentração de poder se acentuou com a derrubada das sublegendas no Congresso Nacional, em prol da qual trabalharam silenciosamente vários governadores. Sem a possibilidade de recorrer à sublegenda para apresentar candidatos próprios, as correntes dissidentes ficaram candidatos à sua sucessão e ao Senado que puderam ser escolhidos nomes com pouco "trânsito" no Partido Democrático Social (PDS), o que reduziu muito suas chances eleitorais e acabou amplificando a vitória das oposições em 15 de novembro de $1982^{11}$.

Desta maneira, a execução do projeto de institucionalização, além de prejudicada pelo movimento de democratização que fortalecia a oposição política, foi enfraquecida "por dentro", tanto pelas disputas entre os militares como pelas dificuldades crescentes que surgiam na constituição de uma elite civil conservadora, com um mínimo de unidade para conduzi-lo.

Nas eleições de 1982, o regime militar colheu parte dos resultados do fracasso do projeto de institucionalização. O governo, mesmo conservando-se majoritário no Senado, perdeu a maioria absoluta na Câmara dos Deputados, pois o PDS elegeu 235 representantes ao passo que os quatro partidos de oposição (PMDB, PDT,PTB e PT) obtiveram 244 cadeiras. Nas eleições para a chefia dos governos dos 23 estados, os partidos de oposição elegeram 10 governadores (o PMDB elegeu nove e o PDT um), passando a dirigir os maiores estados, São Paulo, Minas Gerais e Rio de Janeiro.

É bem verdade que, mesmo assim, os responsáveis de turno pelo regime militar ainda pareciam, para grande parte dos analistas, ter o controle do sistema político e das transformações que aí ocorriam. O partido oficial podia dominar as votações conjuntas do Congresso porque sua maioria no Senado o permitia. Além disso, mesmo nas decisões em que a Câmara dos Deputados decidia isoladamente, o governo podia contar, é o que se imaginava, com o auxílio dos representantes do PTB para dar a vitória ao PDS.

Por último, e isso valia mais do que tudo, o regime militar-autoritário conseguira assegurar, em princípio, sua continuidade, porque as regras eleitorais vigentes lhe davam uma maioria de 38 votos no Colégio Eleitoral responsável pela escolha do próximo presidente da República, a se realizar em janeiro de 1985. É certo que, naquele momento, contando com pequena maioria no Congresso Nacional e já sem dispor dos atos institucionais, o governo militar dependia, em grande medida, para ter maioria no Colégio Eleitoral, dos representantes das assembléias legislativas dos estados que faziam parte do colegiado. Mas isso, na época, não parecia constituir problema para o comando do regime militar-autoritário, que parecia ainda ter o controle sobre o processo político e, portanto, dava por suposto o assentimento das elites regionais e dos governadores favoráveis ao regime que, em última instância, escolheriam aqueles reprsentantes ${ }^{12}$.

De fato, só a partir da chamada "crise da dívida" é que as tensões embutidas no processo de mudança anterior multiplicar-se-iam a ponto de tornarem inviável a preservação do regime militar. E nisso, como se verá, a insurgência dos estados da federação terá um papel de destaque. 
SALLUM JR., Brasilio. Federação, autoritarismo e democratização. Tempo Social; Rev. Sociol. USP, S. Paulo, 8(2): 27-52, outubro de 1996.

\section{A democratização e o despontar da nova federação}

A partir de 1982, os responsáveis pelo regime autoritário perderam boa parte do controle sobre o processo de liberalização que haviam desencadeado em 1973. De fato, a liberalização foi atropelada pela crise do Estado nacional-desenvolvimetista que sustentava o regime militar e dera suporte às formas político-institucionais de domínio que o precederam desde os anos 30 .

Dois processos abrangentes estiveram na raiz da crise do Estado nacional-desenvolvimentista. De um lado, ele foi solapado pelo processo de democratização da sociedade, que ganhara impulso da vigorosa expansão capitalista iniciada no final dos anos 60, mas que só apresentou seus primeiros frutos políticos a partir de meados dos anos 70. As vitórias eleitorais da oposição partidária, iniciadas em 1974, foram expressões políticas típicas da democratização. No entanto, sua manifestação mais avançada foi o novo sindicalismo operário surgido na região do $\mathrm{ABC}$ no Estado de São Paulo. De outro lado, o Estado desenvolvimentista entrou em crise também em função da ação de centros internacionais de poder que ganharam preeminência no país em razão da internacionalização da economia. O estrangulamento externo da economia brasileira teve início em 1979, com a alta extraordinária dos juros externos e do preço do petróleo. Mas só atingiu seu clímax em 1982, com a interrupção dos fluxos voluntários de empréstimos externos para o país.

Não é o caso aqui de retomar a análise da transição política brasileira, mas vale anotar que tais processos, de democratização da sociedade e de estrangulamento externo da economia, só forneceram as condições gerais para mudança ${ }^{13}$. Colocaram em xeque o Estado nacional-desenvolvimentista mas não o destruíram. Outros processos mais específicos - inclusive a estratégia de superação da crise adotada pelos que então comandavam o Estado - também contribuíram para desagregá-lo. Com isso, a tentativa de institucionalização do regime, que se ancorava na força do Estado desenvolvimentista, perdeu impulso e foi superada por um outro tipo, este não planejado, de mudança política, o processo de democratização. É essa reorientação do processo político, que começa a ocorrer a partir do final de 1982 e ao longo de 1983 e 1984, que inviabiliza a continuação do regime militar-autoritário.

É certo que não haverá nesse curto período qualquer ruptura político-institucional a demarcar a inflexão política antes apontada. Entretanto, houve aí mudanças importantes nas relações efetivas de poder que dão sustentação a qualquer ordem política. Mudanças que esvaziaram o caráter autoritário da legalidade vigente, e que passaram a dar suporte a uma outra ordem política mais democrática que só começaria a ganhar forma jurídica a partir do governo José Sarney.

Essas mudanças afetaram as relações entre os vários centros de poder - executivo federal, estados, municípios e Congresso Nacional; as relações com reduzida margem de manobra... O golpe final nas dissidências foi desferido pela vinculação total dos votos.[...] Nada impede, porém, que as correntes derrotadas nas convenções tentem boicotar o candidato escolhido no próprio dia da eleição. Para isso, basta que tais correntes recomendem aos seus seguidores o uso do 'voto camarão' - no qual a cabeça da chapa, justamente onde está o nome do governador, é deixada em branco". (Isto é, 12/05/1982).

12 A Emenda Constitucional 22, de junho de 1982, estabeleceu que os 6 representantes de cada estado no Colégio Eleitoral seriam eleitos pela bancada do partido majoritário na respectiva assembléia legislativa, e não mais pela assembléia como um todo, o que dava mais peso aos governadores.

13 Analiso de forma mais extensa esta fase da transição política brasileira em Labirintos - dos generais à nova república (Sallum Jr., 1996, cap. 2). 
dos centros de poder político com a massa da população; e a sucessão presidencial.

Focalizarei aqui, é claro, as alterações ocorridas nas relações federativas.

A inflexão entre a liberalização e democratização política foi marcada, ao mesmo tempo, pela grande conquista eleitoral das oposições em novembro de 1982 e pela crise da dívida externa que conduziu à moratória de dezembro do mesmo ano. Esses dois episódios foram também o grande divisor de águas nas relações políticas entre a União e os estados.

Juan Linz, em texto marcante, chamou a atenção para o fato de que a eleição direta dos governadores de estado em 1982 introduziu no sistema político uma "diarquia", a coexistência de duas fontes de legitimação do poder, uma proveniente da lógica autoritária do regime militar e a outra resultante da vontade popular expressa em eleições diretas (cf. Linz, 1993).

É claro que essa coexistência sempre esteve presente no regime autoritário, mas não tinha aí conseqüências muito importantes do ponto de vista do exercício do poder. Mesmo assim, é inegável que a partir das eleições e da posse dos governadores eleitos em 1982 a dinâmica política mudou. Mas, não apenas em função da mencionada duplicidade das fontes de legitimidade. E nem mesmo porque, além disso, os governadores que passaram a exercer o poder graças ao voto popular apropriaram-se de recursos políticos importantes, com os quais ganharam melhores condições de luta com a União.

A dinâmica política mudou também porque, em meio à crise econômica, executivo federal e governos de estado passaram a constituir-se em pólos opostos também no que se refere à política monetária e fiscal. De fato, frente à crise da dívida, exacerbada pela interrupção do fluxo voluntário de recursos externos, o governo da União adotou uma política de "ajuste" que favorecia exportações e restringia as atividades internas para produzir megasuperávits comerciais, destinados a pagar as obrigações externas. Para isso, o governo federal elegeu como prioridade a redução do déficit público, promovendo cortes de gastos correntes e de investimentos governamentais em todos os âmbitos, inclusive nos estados e municípios. Os estados, no pólo oposto, além de terem sua capacidade de arrecadação própria diminuída devido à recessão, de verem suas obrigações financeiras aumentar graças aos credores e à política da União, viram-se também à mercê das restrições do governo central no que se refere às transferências voluntárias de recursos federais, muito significativas na época.

Este último foco de tensão, vinculado às bases materiais da federação, alimentou de forma permanente os conflitos políticos ocorridos entre o governo federal e os estados nos dois últimos anos do regime militarautoritário.

A política restritiva da União em relação aos estados e municípios foi executada, de forma muito consistente e eficaz, pela equipe econômica do presidente Figueiredo, liderada por Antônio Delfim Neto. 
SALLUM JR., Brasilio. Federação, autoritarismo e democratização. Tempo Social; Rev. Sociol. USP, S. Paulo, 8(2): 27-52, outubro de 1996.

No caso das finanças públicas, os resultados alcançados pela União foram excepcionais. $\mathrm{O}$ déficit público, de responsabilidade de estados e municípios, caiu de 1,6\% do PIB em 1982 para 0,3\% em 1983. Em 1984, as contas desses âmbitos da Federação fecharam com um superávit de $0,4 \%$ do PIB.

É claro que os governadores resistiram às restrições do governo federal o quanto puderam. Procuram, por exemplo, livrar-se dos controles financeiros com os quais a União tentava "ajustar" os estados ao modelo de repactuação com os credores propugnado pelo FMI. No entanto, nos anos de 1983 e 1984, os estados só conseguiram escapar dos estreitos limites de endividamento impostos pela Resolução ${ }^{\circ} 831$ do Banco Central atrasando o pagamento de suas obrigações ${ }^{14}$.

Essa rigidez em relação ao "ajuste" dos estados provocou reações, no entanto, principalmente entre os governadores do PDS, resultando na abertura de fendas importantes na unidade política que tinham com o governo central ${ }^{15}$.

Ainda em 1983, essas reações materializaram-se em um movimento pela ampliação da participação das unidades subnacionais na receita tributária, de forma a reduzirem sua dependência em relação às transferências voluntárias da União. O movimento culminou com a aprovação pelo Congresso, em novembro de 1983, da Emenda Passos Porto, do PDS, segundo a qual estados e municípios tiveram aumentados seus respectivos fundos de participação nos tributos arrecadados pela União (FPE e FPM).

Dois pontos devem ser ressaltados a propósito dessa redistribuição da carga tributária.

Em primeiro lugar, a pressão dos governadores e prefeitos nasceu, é verdade, da crise econômica que exacerbou a penúria das finanças estaduais e sua crônica dependência em relação à União. No entanto, o que permitiu o sucesso do movimento de pressão junto ao Congresso foi que a lógica eleitoral já tinha passado a ser um elemento importante nos cálculos dos parlamentares. Ora, em função do sistema eleitoral vigente, o sucesso eleitoral dependia menos do apoio do governo federal do que de prefeitos e governadores. Por isso, o governo federal, premido por um Congresso cada vez mais sensível às pressões populares de impacto eleitoral e pela necessidade de manter a unidade governista na questão sucessória (a ser decidida em janeiro de 1985), terminou por assimilar - parcialmente, é verdade - as reivindicações dos governadores. Em 1984, a emenda constitucional Airton Sandoval ampliaria mais ainda essa participação na arrecadação federal.

Em segundo lugar, vale sublinhar que as mudanças tributárias de 1983 e 1984 não devem ser confundidas com o processo de descentralização ocorrido a partir do governo Geisel. Essa desconcentração tributária em favor das esferas subnacionais fazia parte da estratégia de liberalização controlada e desenvolvida sob o comando da dupla Geisel/Golberi. Na época, era a União que comandava o processo. As mudanças de 83-84, pelo contrário, foram "arrancadas" de um executivo federal - enfraquecido pela crise econômica e
${ }^{14}$ A Resolução no 831 do Banco Central data de $9 / 06 / 83$ e determinava a fixação de tetos periódicos (normalmente inferiores às correções monetária e cambial) para a expansão das operações de crédito das instituições financeiras e sociedades de arrendamento mercantil ao setor público. Isso quer dizer que o BC fixava os limites máximos de "rolagem" das dívidas e, portanto, um montante mínimo de pagamento do principal. Ver, a esse respeito, Tomás B. de Paula et alii (1992, p. 11-28)

${ }^{15}$ Os governadores vinculados à oposição mantiveram certa distância e discrição em relação à essa disputa. Temiam provocar reações do governo que lhes tirassem as conquistas políticas obtidas. 
SALLUM JR., Brasilio. Federação, autoritarismo e democratização. Tempo Social; Rev. Sociol. USP, S. Paulo, 8(2): 27-52, outubro de 1996.

${ }^{16}$ Consultar a respeito do uso das máquinas políticas estaduais Fernando Abruccio (1995, esp. cap. III e IV).

${ }^{17} \mathrm{Em} 15$ de janeiro de 1985, o candidato da Aliança Democrática, Tancredo Neves, obteve 480 votos contra 180 de Paulo Maluf. Houve 17 abstenções e 9 ausências. Após as eleições de 1982, calculava-se uma diferença de 38 votos a favor do PDS. cioso de seus recursos - pela pressão de prefeitos, governadores e parlamentares. Já não expressavam a lógica da liberalização controlada, mas a desagregação do núcleo do poder autoritário e o avanço das forças democratizantes. Ou melhor, o avanço dos centros de poder que no interior do Estado autoritário faziam parte e expressavam as forças favoráveis àquela mudança política.

Essa última observação nos remete à atuação dos governadores de oposição nesse mesmo período. Enquanto os governadores ligados ao PDS concentraram-se em 1983 na disputa de recursos materiais com a União, os vinculados à oposição nuclearam sua atuação na arena em que a sociedade questionava sua exclusão política pelo Estado. De fato, a partir dos segundo semestre de 1983, os governadores de oposição ao regime militar começaram a organizar o que viria a ser o maior movimento de massas que o País já conhecera, a Campanha das Diretas, desencadeada em janeiro de 1984. Multiplicaram ao máximo os impulsos democratizantes nascidos da sociedade com os recursos políticos conquistados nas eleições de $1982^{16}$. E canalizaram tais impulsos em favor da quebra da regra de sucessão presidencial que tendia a prolongar a vida do regime militar-autoritário excluindo do processo eleitoral a massa da população.

Mesmo que o movimento para mudar a regra sucessória tenha fracassado em alcançar seu objetivo imediato - a emenda constitucional que introduzia eleições diretas para a Presidência foi derrotada - a campanha cristalizou na maioria da população o oposicionismo ao regime militar. E mais do que isso, dividiu as hostes governistas, tornando inviável para o regime conseguir por suas próprias forças uma vitória no Colégio Eleitoral.

Em suma, as rachaduras produzidas pela crise e pela política econômica governamental no Estado, no regime e no seu "federalismo de integração" e, além delas, as pressões democratizantes, nascidas da sociedade e multiplicadas pela oposição política, acabaram por fragilizar a hierarquia entre os centros de poder político que caracterizava a ordem autoritária.

A luta sucessória travada em 1984 exacerbou a autonomia política dos parlamentares e dos governadores de Estado. Estes últimos, especialmente, assumiram com desenvoltura cada vez maior o papel de grandes eleitores, comandando com independência em relação ao governo central o voto dos representantes das assembléias estaduais no Colégio Eleitoral. Foram eles, inclusive os do PDS, que garantiram a contundência da derrota do núcleo duro do regime militar, representado pela candidatura Paulo Maluf, no Colégio Eleitoral ${ }^{17}$.

Desta forma, foram os centros de poder que tinham posições subalternas no regime militar-autoritário - Congresso, estados e municípios que deram o arremate final na destruição da ordem autoritária e na construção na "Nova República". Digo arremate final porque eles só tiveram papel tão importante na queda do velho regime e na construção do novo porque foram impulsionados pelo movimento de democratização e pelas vicissitudes da 
SALLUM JR., Brasilio. Federação, autoritarismo e democratização. Tempo Social; Rev. Sociol. USP, S. Paulo, 8(2): 27-52, outubro de 1996.

internacionalização da economia brasileira, que vinham há algum tempo desagregando o Estado desenvolvimentista e a sociedade autocrática, alicerces da ordem institucional autoritária construída pelos militares.

\section{Considerações finais}

As transformações políticas que conduziram ao fim do regime militar-autoritário parecem confirmar a crença de que a história política brasileira tem sido uma série sucessiva de sístoles e diástoles em que o poder ora se concentra autoritariamente na União, ora se dispersa democraticamente, ancorando-se nos estados federados.

Mas, não estarão aqueles que crêem nesta sucessão contínua de sístoles e diástoles abstraindo as bases sociais dos movimentos políticos e transformando-os em fórmula vazia? Um exame mais cuidadoso dos processos analisados até aqui nos abriga, de fato, a colocar em dúvida a abrangência daquela assertiva.

Sim, porque o movimento de dispersão ocorrido a partir de 1974 obedeceu a dois padrões diversos de mudança: a liberalização e a democratização. O primeiro padrão, iniciado e controlado pela cúpula do regime militar e destinado a preservar formas limitadas de participação popular na vida pública. O segundo, impulsionado pela base da sociedade e facilitado pelo contexto internacional, potenciado pelos centros políticos subalternos do regime militar e tendente a garantir ao conjunto da população plena participação política.

Só abstraindo os seus significados no plano societário que se torna possível identificar os dois movimentos como meras fases sucessivas e progressivas de uma mesma diástole. Com efeito, entre a liberalização e a democratização política ocorreu uma mudança tão grande no plano societário que talvez não se deva mais identificar, necessariamente, centralização com autoritarismo e descentralização com democracia.

Não insistirei no já sabido: que o capitalismo industrial expandiuse extraordinariamente no Brasil até o começo dos anos 80 , seja incorporando novos ramos de produção ao seu parque produtivo, seja expandindo-se por boa parte das regiões do país; que houve uma expansão enorme do proletariado urbano e rural, uma incorporação extensa das mulheres ao mercado de trabalho e um crescimento extraordinário da classe média assalariada. Todas essas transformações estão a indicar que ocorreu nos últimos anos uma autêntica revolução na estrutura social brasileira, não só com o urbano dominando o rural, como já ocorria no começo do século, mas com a indústria dominando a agricultura, industrializando-a, com o capitalismo absorvendo a atividades econômicas em todo o território nacional e fazendo do trabalho assalariado a forma quase exclusiva de trabalho no país. Estamos longe, portanto, do Brasil composto de ilhas regionais em que a atividade industrial e a agricultura capitalista absorviam só parcialmente as atividades econômicas. 
Essas são as bases socioeconômicas do novo sindicalismo, nascido na segunda metade dos anos 70, da expansão extraordinária das associações populares e de classe média, dos movimentos sociais, do avanço eleitoral contínuo da oposição política, da construção de uma organização política própria dos trabalhadores, da campanha das diretas e do encerramento do ciclo de generais-presidentes. Isso para não mencionar eventos posteriores ao período em estudo.

Não se estará diante de algo próximo daquilo que Sergio Buarque de Holanda denominava "revolução vertical"? Daquilo que ele imaginava poder superar as oscilações meramente horizontais, porque pertencentes ao mesmo registro oligárquico, entre caudilhismo e liberalismo (cf. Holanda, 1993, cap. VII)? Não estaremos diante dos inícios de um processo social e político que tende a expandir com vigor no Brasil aquilo que Florestan Fernandes denominava ordem social competitiva?

É evidente que não há como responder a essas questões nos limites desse artigo. Mesmo porque ele cobre um período histórico muito limitado, insuficiente como base empírica para uma resposta consistente.

No entanto, a sinalização das diferenças entre os processos recentes de liberalização e democratização política permite chamar a atenção para a necessidade de avaliar de forma mais nuançada as oscilações da federação. O fato de que na raiz da democratização política está um processo mais amplo de democratização da sociedade abre a possibilidade de que uma organização mais centralizada do poder de Estado não signifique necessariamente concessão ao autoritarismo político. Ou que a autonomização acentuada dos estados não seja sinônimo de expansão da democracia. Com efeito, na medida em que se constitui no Brasil uma democracia com sólidas bases societárias, os simples movimentos de sístole e de diástole das relações federativas tendem a não indicar mais, de forma tão simples e direta, os recuos e os avanços das liberdades políticas no país.

A necessidade de uma avaliação mais nuançada dessas questões é tanto mais necessária porque o processo de democratização do país vem ocorrendo ao mesmo tempo em que ele se insere de modo mais fundo no sistema capitalista internacional. Isso significa que as diferentes formas de organização da federação não se referem mais a um Estado que exerce de forma constante sua soberania frente a um sistema de estados nacionais igualmente soberanos. Essas diferentes formas dizem respeito a um Estado nacional cuja capacidade de exercer poder de forma soberana está se reduzindo, tal como o sistema de estados de que faz parte, frente à transnacionalização da economia e da sociedade. 
SALLUM JR., Brasilio. Federação, autoritarismo e democratização. Tempo Social; Rev. Sociol. USP, S. Paulo, 8(2): 27-52, outubro de 1996.

SALLUM JR., Brasilio. Federation, authoritarian rule and democratization. Tempo Social; Rev. Sociol. USP, S. Paulo, 8(2): 27-52, october 1996.

ABSTRACT: The article deals with the federative relations under the Brazilian authoritarian regime, settled in 1964 by a military coup d'État. Federative relations are studied in diferent phases of the authoritarian period: the first and hardest one which remains untill 1973; the liberalization phase, from 1974 to 1982; and the decadent phase of the military rule, from 1983 untill the beginning of 1985 . The article underlines the different features of federative relations (economical, electoral and military). The article also debates usual interpretations of Brazilian federative relations which consider authoritarism the concentration of power in central government and democracy the increased authonomy of the federative states.

\section{REFERÊNCIASBIBLIOGRÁFCAS}

Abruccio, Fernando.(1995) Os Barões da Federação. São Paulo, dissertação (Mestrado). Faculdade de Filosofia Letras e Ciências Humanas da Universidade de São Paulo.

Affonso, Rui. (1988) Federalismo tributário e crise econômica (Brasil: 1975-85). São Paulo, dissertação (Mestrado). Instituto de Economia, Universidade de Campinas.

Alves, Maria Helena Moreira. (1990) Estado e oposição no Brasil (19641984). 4 edição. Petrópolis, Ed. Vozes.

Assis, José Carlos. (1988) Análise da crise brasileira: da internacionalização bancária com Castelo à capitulação externa com Sarney. Rio de Janeiro, Ed. Forense.

CAno, Wilson. (1979) As raízes da concentração industrial em São Paulo. São Paulo, Difel.

CArdoso, Fernando Henrique. (1973) O Modelo Político Brasileiro. $2^{\mathrm{a}}$ edição. São Paulo, Difel.

Dias, Guilherme da Silva \& Aguirre, Basilia. (1993) Crise políticoeconômica: as raízes do impasse. In: Sola, Lourdes (org.). Estado, mercado e democracia. Rio de Janeiro, Paz e Terra.

Holanda, Sergio Buarque de. (1993) Raízes do Brasil. 25 edição. Rio de Janeiro, José Olympio Editora.

KLEIN, Lúcia. (1978) Brasil pós-64: a nova ordem legal e a redefinição das bases de legitimidade. In: $\&$ Figueiredo, Marcus. Legitimidade e coação no Brasil pós-64. Rio de Janeiro, ForenseUniversitária.

LINZ, Juan. (1983) The transition from authoritharian regimen to democracy in Spain, some thoughts for Brazilians. (mimeo). Yale University.

\author{
UNITERIMS: \\ Brazil, \\ federation, \\ military forces, \\ authoritarism, \\ democratization, \\ State, \\ crisis, \\ political transition, \\ development.
}


Medeiros, Antonio Carlos de. (1986) Politics and intergovernmental relations in Brazil (1964-1982). London, Doctoral Thesis. London School of Economics and Political Science.

OliveIRA, Eliézer Rizzo de. (1976) As forças armadas: política e ideologia no Brasil (1964-69). Petrópolis, Vozes.

OliveIRA, Fabrício Augusto de. (1981) A reforma tributária de 1966 e a acumulação de capital no Brasil. São Paulo, Ed. Brasil/Debates.

Paula, Tomás B. et alii. (1992) Estudo sobre o controle dos limites de endividamento da união, estados e municípios. (mimeo). São Paulo, Projeto IPEA-PNUD/FUNDAP.

SAllum JR., Brasilio. (1996) Labirintos - dos generais à nova república. São Paulo, Ed. Hucitec.

Viana Filho, Luís. (1976) O governo Castelo Branco. $3^{\text {a }}$ edição. Rio de Janeiro, José Olympio Editora. 